\title{
Survey and Distribution of Terrestrial Snails in Fruit Orchards and Ornamental Plants at Alexandria and EL-Beheira Governorates, Egypt
}

\author{
EL-Sayed H.Eshra 1
}

\begin{abstract}
Terrestrial snails were surveyed at Alexandria and EL-Beheira governorates in northwestern Egypt. Five land snail species at Abees region on grape orchard including Eobania vermiculata, Theba pisana, Helicella vestalis, Monacha obstructa and Oxychillus alliarius; while two species at EL-Mamoura region on ornamental plants including $E$. vermiculata and $T$. pisana were recorded in Alexandria governorate. In EL-Beheria governorate, three land snail species including $T$. pisana, $H$. vestalis and $M$. obstructa were recorded on navel orange and apple trees at Kafr EL-Dwar center and E. vermiculata, $T$. pisana and $C$. acuta were found on ornamental plants at Abulmatamir center. The most abundant species were $\boldsymbol{T}$. pisana and E. vermiculata at Alexandria (71.4 and 25.5\%) and El-Beheira (65.6 and $14.2 \%)$ respectively, while the lowest found were $O$. alliarius $(0.5 \%)$ at Alexandria and M. obstructa (4.1\%) at EL-Beheira.
\end{abstract}

Key words: Terrestrial snails, Survey, Distribution, Alexandria, El-Beheira, Egypt.

\section{INTRODUCTION}

The terrestrial mollusks are considered as major pests of a wide range of agricultural and horticultural crops in temperate and humid habitats worldwide (Speiser and Kistler 2002). They attack plants causing great damage to the cultivated plants (Godan 1983). Economic damage caused by these mollusks is due to feeding and to contamination with their bodies, faces or slime leading to deterioration of the product quality, in addition the financial loss (Iglesias et al. 2003). Furthermore, some gastropods work as intermediate hosts for many parasitic worms infesting man and his domestic animals (Barker 2002). In Egypt terrestrial snails attack vegetables, field crops, orchard trees as well as ornamental and medical plants (Bishara et al.1968, EL-Okda1980, EL-Wakil et al. 2000). The land snails Eobania vermiculata, Theba pisana, Helicella vestalis, Monacha obstructa, Cochlicella acuta were recorded in many Egyptian governorates attacking various plantations (Kassab and Daoud 1964, EL-Okda1979, El-Deeb et al. 1996, Abu-bakr 1997, Eshra 2004). The main aim of this work is to get more information about survey, population density and distribution of land snails in four different localities at

\footnotetext{
${ }^{1}$ Plant Protection Research Institute, Agriculture Research Center, Alexandria, Egypt.

Email: eheshra@yahoo.com

Received May 16, 2013, Accepted June 26, 2013
}

Alexandria and EL-Beheira Governorates on various plants.

\section{MATERIALS AND METHODS}

The field experiments were conducted in Abees and EL-Mamoura regions at Alexandria Governorate and Kafr El-Dwar and Abulmatamir regions at EL-Behira Governorate during the two spring seasons 2011 and 2012. At Alexandria, grapes (Vitis vinefera) orchard in Abees region and some ornamental plants including crinum onion (Crinum thaianum), royal poinciana (Delonix regia) rose (Rosa spp.), ficus (Ficus elastica), gerbera (Gerbera spp.), copperleaf (Acalypha spp.) and silver dust (Senecio cineraria) in EL-Mamoura region were exposed to survey. At EL-Behira, navel orange (Citrus sinesis) and apple (Pyrus malus L.) orchards in Kafr EL-Dwar region as well as ornamental plants, santolina (Artemisia sp.), ornamental palm (Latania vershaffeltii), jasmine (Jasminum grandiflorum), rose (Rosa spp.) and hibiscus (Hibiscus spp.) in Abulmatamir region were involved in this study. Land snail species were identified according to the terminology, given by (Godan 1983 and EL-Okda 1984). Samples were taken in early morning by using the quadrate sample $(50 \times 50 \mathrm{~cm})$ in ornamental plants (Staikou et al. 1990). Ten samples were randomly taken from each crop. The snails were recorded on both plant and soil surface in quadrate. Moreover, ten fruit trees were randomly chosen to count snails one time every month through two consecutive spring seasons. The snails on both tree and on soil surface around the tree $(50 \times 50 \mathrm{~cm})$ were recorded. The population density and percentage of frequency values as well as distribution of the identified snail species were recorded.

\section{RESULTS AND DISCUSSION}

Population density and occurrence of the land snails at Alexandria and EL-Beheira Governorates.

Land snail samples were collected from some ornamental plants and fruit trees at Alexandria Governorate (Abees and EL-Mamoura regions) and EL-Beheira Governorate (Kafr EL-Dwar and the Abulmatamir regions). The results in Table (1) revealed that, six land snail species; Eobania vermiculata, Theba pisana, Helicella vestalis, Cochecella acuta and Monacha obstructa belonging to super family: 
Helicoidea, family: Hellicidae and sub family: Helicellinae and Oxychillus alliarius belonging to super family: Limacoidea, family: Zonitidae and sub family: Zonitinae were recorded in the two governorates.

The land snail species $T$. pisana and E. vermiculata were the most abundant in all regions. The calculated total average of population densities and frequencies of occurrence were 9832 and $69.8 \%$ for $T$. pisana and 3173 and $22.6 \%$ for $E$. vermiculata, respectively. Higher population densities of $T$. pisana (14772, $71.4 \%)$ and $E$. vermiculata $(5286,25.5 \%)$ were recorded at Alexandria than those at EL-Beheira regions $(4893,65.6 \%)$ and $(1060,14.2 \%)$, respectively. It is interesting to notice that, the snail $C$. acuta disappeared in this survey from Alexandria regions, while $O$. alliarius snail was not found in EL-Beheria regions.

Data in Table (2) showed that there are five land snail species at Abees region and two species at ELMamoura region of Alexandria Governorate. EL-
Mamoura region was highly infested with $T$. pisana $(13930,74.7 \%)$ snail in comparison with Abees region (842, 41.0\%). E. vermiculata exhibited relatively moderate population densities and frequencies of occurrence in Abees and EL-Mamoura localities (576, $28.1 \%)$ and $(4710,25.3 \%)$, respectively. On the other hand, in Abees region, $H$. vestalis, M. obstructa, $O$. alliarius snails were found in relatively low population densities and frequencies of occurrence with (341, $16.6 \%),(189,9.2 \%)$ and $(107,5.2 \%)$ respectively. The land snail C. acuta was not recorded in the two regions at Alexandria Governorate. Also species of $H$. vestalis, $M$. obstructa and $O$. alliarius snails were not found in EL-Mamoura region. At EL-Beheria Governorate, data showed that the presence of three land snail species; $T$. pisana, $H$. vestalis and M. obstructa in Kafr EL-Dwar region and E. vermiculata, T. pisana and C. acuta were found in the Abulmatamir region. T. pisana was the most abundant species in Kafr EL-Dwar and Abulmatamir localities with high population densities

Table 1. Population density of common land snail species infested fruit orchards and ornamental plants at Alexandria and EL-Beheira Governorates

\begin{tabular}{|c|c|c|c|c|c|c|}
\hline \multirow{3}{*}{ Land snails } & \multicolumn{4}{|c|}{ Governorates } & \multirow{2}{*}{\multicolumn{2}{|c|}{ Total average }} \\
\hline & \multicolumn{2}{|c|}{ Alexandria } & \multicolumn{2}{|c|}{ EL-Beheira } & & \\
\hline & P.D.* & F.O. $\% * *$ & P.D.* & F.O. $\% * *$ & P.D.* & F.O. $\% * *$ \\
\hline Eobania vermiculata & 5286 & 25.5 & 1060 & 14.2 & 3173 & 22.6 \\
\hline Theba pisana & 14772 & 71.4 & 4893 & 65.6 & 9832 & 69.8 \\
\hline Helicella vestalis & 341 & 1.7 & 500 & 6.7 & 420 & 3.0 \\
\hline Cochecella acuta & --- & --- & 700 & 9.4 & 350 & 2.5 \\
\hline Monacha obstructa & 189 & 0.9 & 300 & 4.1 & 245 & 1.7 \\
\hline Oxychillus alliarius & 107 & 0.5 & 0 & 0.0 & 54 & 0.4 \\
\hline Total & 20695 & $\begin{array}{ll}--- \\
--1\end{array}$ & 7453 & $\begin{array}{ll}--- \\
-\end{array}$ & 14074 & --- \\
\hline
\end{tabular}

P.D.: Population density*

**F.O.: Frequency of occurrence

Table 2. The distribution of population density of some land snail species at Alexandria and EL-Beheira Governorates

\begin{tabular}{|c|c|c|c|c|c|c|c|c|}
\hline \multirow{4}{*}{ Land snails } & \multicolumn{8}{|c|}{ Governorates } \\
\hline & \multicolumn{4}{|c|}{ Alexandria } & \multicolumn{4}{|c|}{ EL-Beheira } \\
\hline & \multicolumn{2}{|c|}{ Abbes } & \multicolumn{2}{|c|}{ EL-Mamoura } & \multicolumn{2}{|c|}{ KafrEL-Dwar } & \multicolumn{2}{|c|}{ Abulmatamir } \\
\hline & P.D.* & F.O. $\% * *$ & P.D.* & F.O. $\% * *$ & P.D.* & F.O.\%** & P.D.* & F.O. $\% * *$ \\
\hline Eobania vermiculata & 576 & 28.0 & 4710 & 25.3 & --- & --- & 1060 & 21.4 \\
\hline Theba pisana & 842 & 41.0 & 13930 & 74.7 & 1713 & 68.2 & 3180 & 64.4 \\
\hline Helicella vestalis & 341 & 16.6 & --- & --- & 500 & 19.9 & --- & --- \\
\hline Cochecella acuta & $\begin{array}{ll}--- \\
\end{array}$ & $\begin{array}{ll}--- \\
\end{array}$ & --- & $\begin{array}{ll}-- \\
\end{array}$ & $\begin{array}{ll}-- \\
\end{array}$ & --- & 700 & 14.2 \\
\hline Monacha obstructa & 189 & 9.2 & --- & --- & 300 & 11.9 & --- & --- \\
\hline Oxychillus alliarius & 107 & 5.2 & --- & --- & --- & --- & --- & --- \\
\hline Total & 2055 & --- & 18640 & --- & 2513 & --- & 4940 & --- \\
\hline
\end{tabular}

P.D.: Population density*

F.O. : Frequency of occurrence 
and frequencies of occurrence $(1713,68.2 \%$ and $(3810$, $64.4 \%$ ), respectively, followed by $H$. vestalis (500, $19.9 \%)$ and $M$. obstructa $(300,11.9 \%)$ at Kafr ELDwar, however E. vermiculata $(1060,21.4 \%)$ and $C$. acuta $(700,14.2 \%)$ became after $T$. pisana in ranking in Abulmatamir region. In general, the results revealed that the land snails $T$. pisana and E. vermiculata were the most predominant species in Alexandria and ELBeheira Governorates.

These results were in harmony with those reported by several researchers (Kassab and Daoud 1964, Bishara et al., 1968, EL-Okda 1980 and Eshra 1997). It could be concluded that E. vermiculata, $T$. pisana and $H$. vestalis snails were the most presented species in the agricultural fields (EL-Deeb et al.,1998). Moreover, Hashem et al. (1992) found that T. pisana and C.acuta were the dominating species recorded on citrus orchards at EL-Amryia region Alexandria Governorate.

Survey of land snails in fruit orchard and ornamental plants at Alexandria Governorate.

Survey and distribution of terrestrial gastropods have been studied in different locations in Alexandria Governorate. Data in Table (3) revealed that, land snail species E. vermiculata, $T$. pisana, $H$. vestalis, $M$. obstructa and $O$. alliarius were recorded in grape orchard at Abees region during two spring seasons of 2011 and 2012. The highest percentages of snails were recorded for $T$. pisana snail $(39.9 \%$ and $41.9 \%)$ followed by $E$. vermiculata $(26.6 \%$ and $29.3 \%)$ and $H$. vestalis $(19.1 \%$ and $14.3 \%)$,while the lowest percentages of snails were recorded for M. obstructa $(10.0 \%$ and $8.5 \%)$ and for $O$. alliarius $(4.4 \%$ and $6.0 \%)$.

Table(4) shows the survey of land snails on ornamental plants in EL-Mamoura region, Alexandria Governorate during two spring seasons (2011 and 2012). Results showed that $E$. vermiculata and $T$. pisana were recorded on C. thaianum, D. regia, Rosa spp., F. elastica, Gerbera spp., Acalypha spp. and $S$. cineraria. A higher density was recorded for $T$. pisana snail in the two spring seasons $(832,561$ snails) than that for E. vermiculata (281,190 snails) on the chosen plants. On the other hand, C. thaianum plants were highly infested with the species of $T$. pisana (31.8, $27.4 \%$ ) and E. vermiculata $(25.8,25.3 \%)$ along the two seasons, respectively.

Table 3. Survey of Land Snails in grape orchard at Abbes region, Alexandria Governorate during two spring seasons

\begin{tabular}{lcccc}
\hline \multirow{2}{*}{ Land Snails } & \multicolumn{2}{c}{ Season 2011 } & \multicolumn{2}{c}{ Season 2012 } \\
\cline { 2 - 5 } & snail / tree* & \% snail & snail / tree* & \% snail \\
\hline Eobania vermiculata & 25.8 & 26.6 & 31.8 & 29.3 \\
\hline Theba pisana & 38.6 & 39.9 & 45.6 & 41.9 \\
\hline Helicella vestalis & 18.5 & 19.1 & 15.6 & 8.3 \\
\hline Monacha obstructa & 9.7 & 10.0 & 9.2 & 6.5 \\
\hline Oxychilus alliarius & 4.2 & 4.4 & 6.5 & 108.7 \\
\hline Total count & 96.8 & & &
\end{tabular}

*Each values is an average of 10 trees.

Table 4. Survey of Land Snails on ornamental plants at El-Mamoura region, Alexandria Govrnorate during two spring seasons

\begin{tabular}{|c|c|c|c|c|c|c|c|c|}
\hline \multirow{3}{*}{ Ornamental plants } & \multicolumn{4}{|c|}{2011} & \multicolumn{4}{|c|}{2012} \\
\hline & \multicolumn{2}{|c|}{ Eobania vermiculata } & \multicolumn{2}{|c|}{ Theba pisana } & \multicolumn{2}{|c|}{ Eobania vermiculata } & \multicolumn{2}{|c|}{ Theba pisana } \\
\hline & Snail/plant* & $\begin{array}{l}\% \\
\text { snail }\end{array}$ & Snail /plant* & $\begin{array}{c}\% \\
\text { snail } \\
\end{array}$ & Snail /plant* & $\begin{array}{c}\% \\
\text { snail } \\
\end{array}$ & Snail/ plant* & $\begin{array}{c}\% \\
\text { snail }\end{array}$ \\
\hline Crinum thaianum & 72 & 25.8 & 265 & 31.8 & 48 & 25.3 & 154 & 27.4 \\
\hline Delonix regia & 24 & 8.5 & 86 & 10.3 & 27 & 14.2 & 56 & 10.0 \\
\hline Rosa spp. & 35 & 12.4 & 105 & 12.7 & 38 & 20.0 & 127 & 22.0 \\
\hline Ficus elastic & 58 & 20.6 & 133 & 15.9 & 22 & 11.6 & 85 & 15.1 \\
\hline Gerbera spp. & 28 & 9.9 & 74 & 8.9 & 10 & 5.3 & 36 & 6.4 \\
\hline Acalypha spp. & 12 & 4.3 & 57 & 6.8 & 34 & 17.9 & 75 & 13.4 \\
\hline Senecio cineraria & 52 & 18.5 & 112 & 13.8 & 11 & 5.7 & 28 & 5.1 \\
\hline Total count & 281 & & 832 & & 190 & & 561 & \\
\hline
\end{tabular}

*Each values is an average of 10 quadarted sample size $50 \times 50 \mathrm{~cm}$ 
In the first season, F. elastica plants were attacked with E. vermiculata and $T$. pisana $(20.6 \%$ and $15.9 \%)$ followed by $S$. cineraria plants $(18.5 \%$ and $13.8 \%)$ and Rosa spp. plants (12.4\% and $12.7 \%)$, respectively. $E$. vermiculata snail was the most abundant snail $(9.9 \%)$ on Gerbera spp. plants followed by $T$. pisana snail (8.9\%); however, $T$. pisana was the most abundant snail on D. regia (10.3\%) and Acalypha spp. (6.8\%) followed by $E$. vermiculata snail with relatively values $8.5 \%$ and $4.3 \%$ respectively. In the second season, Rosa spp. plants were highly infested by $T$. pisana snail followed by $E$. vermiculata snail with infestation values of $22.0 \%$ and $20.0 \%$, respectively. The highest infestation with $E$. vermiculata was observed in Acalypha spp. followed by $D$. regia then $S$. cineraria with infestation percentages of $17.9,14.2$ and 5.7\%, respectively. F. elastica and Gerbera spp. plants were infested by land snails $T$. pisana $(15.1 \%$ and $6.4 \%)$ followed by E. vermiculata (11.6\%and 5.3\%).

Survey of land snail species in fruit orchard and ornamental plants at EL-Beheira Governorate.

Land snail species were surveyed on certain fruit trees including navel orange $(C$. sinesis) and apple $(P$. malus) orchards at Kafr EL-Dwar, EL-Beheira Governorate, during the two spring seasons (2011 and 2012). The obtained data revealed that $H$. vestalis, $M$. obstructa and $T$. pisana species were common in all fruit trees (Table 5). The mean number of snails differed according to the kind of fruit trees and the season of survey, where they recorded 73.1 and 48.4 snail/tree on C. sinesis, and 75.8 and 54.0 snail/tree on $P$. malus during 2011 and 2012, respectively. T. pisana snail was the most abundant species during the two spring seasons (2011 and 2012) on C. sinesis (64.7 and 70.3\%) and on P. malus (73.1 and 64.1\%), followed by $H$. vestalis and $M$. obstructa.

Data in Table (6) show the survey of land snails on ornamental plants at the Abulmatamir region, ELBeheira Governorate during the two spring seasons 2011 and 2012. The land snails; C. acuta, E. vermiculata and $T$. pisana species were recorded on

Table 5. Survey of Land Snails in fruit orchard at Kafr El-Dwar center, EL- Beheira Govrnorate during two spring seasons

\begin{tabular}{lcccccccc}
\hline \multirow{2}{*}{ Land Snails } & \multicolumn{2}{c}{ Navel orange } & \multicolumn{2}{c}{ Navel orange } & \multicolumn{2}{c}{$\begin{array}{c}\text { Apple } \\
\mathbf{2 0 1 1}\end{array}$} & \multicolumn{2}{c}{$\begin{array}{c}\text { Apple } \\
\mathbf{2 0 1 2}\end{array}$} \\
\cline { 2 - 9 } & snail/tree & \% snail & snail /tree* & \% snail & snail /tree* & \% snail & snail /tree* & \% snail \\
\hline Helicella vestalis & 16.9 & 23.1 & 9.4 & 19.4 & 12.2 & 16.1 & 11.5 & 21.3 \\
\hline Monacha bstructa & 8.9 & 12.2 & 5.0 & 10.3 & 8.2 & 10.8 & 7.9 & 14.6 \\
\hline Theba pisana & 47.3 & 64.7 & 34.0 & 70.3 & 55.4 & 73.1 & 34.6 & 64.1 \\
\hline Total count & 73.1 & - & 48.4 & - & 75.8 & - & 54.0 & - \\
\hline
\end{tabular}

*Each value is an average of 10 trees.
Artemisia sp., L. vershaffeltii, J. grandiflorum, Rosa spp. and Hibiscus spp. plants. In the first season, $T$. pisana snail was recorded with high density (139 snail/plant) followed by E. vermiculata and C. acuta (58 and 45 snail/plant). On the other view, Artemisia sp. and $L$. vershaffeltii were highly infested by $E$. vermiculata snail that recorded 29.5 and $24.1 \%$, respectively, followed by Rosa spp. (18.9\%), J. grandiflorum (17.2\%) and Hibiscus spp. (10.3\%). T. pisana snail was abundant onHibiscus spp. followed by Rosa spp. $>$ L. vershaffeltii $>$ Artemisia sp. $>J$. grandiflorum. Hibiscus spp. and Rosa spp. plants were highly infested with C. acuta (31.2 and 26.8\%) followed by $J$. grandiflorum, Artemisia sp. and $L$. vershaffeltii plants with infestation percentages of 17.8 , 13.1 and $11.1 \%$, respectively. In the second season, also T. pisana snail was recorded with high density (79 snail/plant) followed by E. vermiculata (48 snail/plant) but $C$. acuta snail recorded the lowest number $(25$ snail/plant) on the studied ornamental plants. On the other hand, both Artemisia sp. and L. vershaffeltii plants were highly infested by $E$. vermiculata with percentages of 31.2 and $25.0 \%$ followed by J. grandiflorum, Rosa spp. and Hibiscus spp. with values of 16.7, 14.6 and $12.5 \%$, respectively. The ornamental plants infestations with $T$. pisana snail could be arranged as follow: Hibiscus spp. > Artemisia sp. > Rosa spp. > J. grandiflorum $>$ L. vershaffeltii (Table 6). The highest number of $C$. acuta snail was found on $L$. vershaffeltii and Rosa spp. (28.0 and 24.0\%) followed by Hibiscus spp. and Artemisia sp. (20.0 and 16.0\%), while the lowest number was found with value $12.0 \%$ on $J$. grandiflorum plants.

These results are in agreement with those reported by the findings of EL-Okda (1980 and 1984) at Alexandria Governorate. Baker and Hawake(1990) reported that the land snail $C$. acuta was more common in pastures than in crops especially in spring and summer. Hashem et al. (1993) studied abundance of $C$. acuta on fruit orchards at EL-Beheira Governorate. 


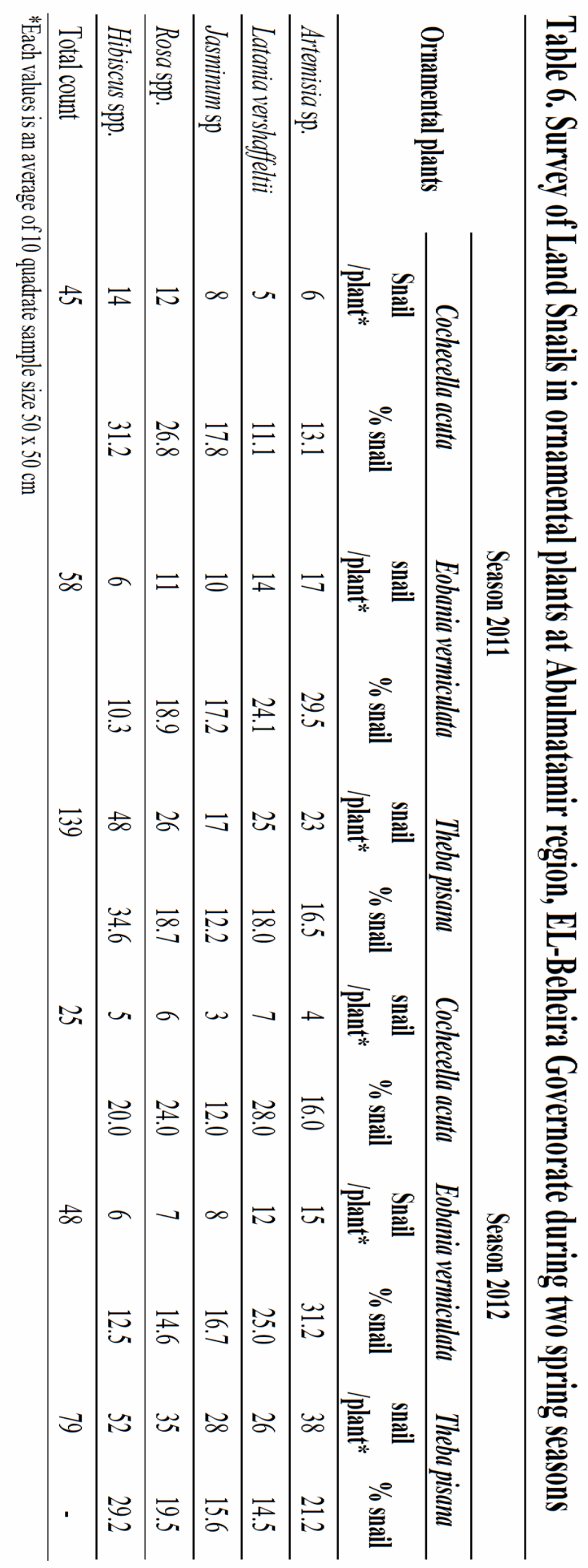


The obtained results showed that the fruit orchards are exposed to snail attacking. These findings are paralleled with that reported by many investigators (Hassanien and Hamed,1989 and Nakhla et al., 1993). Moreover, Sweet basil species as ornamental and aromatic plants were highly infested by C.acuta and T.piana in Alexandria Governorate, Egypt (Hassan, 1999).

\section{REFERENCES}

Abu-Bakr, Y. (1997): Toxicological and environmental studies on some terrestrial gastropods. M.Sc. Thesis Fac. Agric. Alexandria Univ.

Baker, G.H. and Hawake, G.B. (1990): Life history and population dynamics of Theba pisana (Mollusca:Helicidae) in A cereal-Pasture rotation. J. Appl. Ecol., 27: 16 - 29.

Barker, G. M. (2002). Molluscs as crop pests. CAB, International, Walling Forti Oxon 10 DE.UK, 468 pp.

Bishara, S.I., Mahrous, H.S. and Kalliny, S. (1968): Studies on land snails injurious to agriculture in U.A.R. Rev. Zool. Bot. Afr., LXXVII (3-4).

El-Deeb, H.I.; Ghamry, E.M.; El-Hwashy, N. and Essa, N. (1996): Relative abundance of some land snails in certain Governorate of Egypt. J. Agric. Sci. Mansoura Univ., 21: $2977-2983$.

El-Deeb, H.I; Zidan, Z.H.; Wilson, M. and Asran, A.A. (1998): Ecological studies on land mollusca fauna of the newly reclaimed land at Nubaryia Alexandria Governorate. Egypt. J. Agric., Sci 6: 217 - 225.

El-Okda, M.K. (1979): Land snails of economic importance at Alexandria region with some notes on the morphological features, classification, economic damage and population on ornamental plants. Agric. Res. Rev. 57: $125-130$.

El-Okda, M.K. (1980): Land snails of economic importance on vegetable crops at Alexandria and Neighboring regions. Agric. Res. Rev. Egypt 58:79 - 86.

El-Okda, M.K. (1984): Land mollusca Infestation and chemical control in El-Ismaeliah Governorate. Agric. Res. Rev. 61:87:92

El-Wakil, H.B.; Kassem F.A.; Abdallah E.A. and Abo-Bakr, Y. (2000): Ecological and biological studies on some terrestrial gastropod species in Alexandria and ElBeheira, Egypt. Alex. J. Agri. Res. 45: 207 - 224.
Eshra, E. H. (1997): Ecological and biological studies on land snails associated with some important economic crops. M.Sc. Thesis, Fac. Agric., Al Azhar Univ., Egypt. pp. 153.

Eshra, E. H. (2004). Studies on terrestrial mollusca at some Governorates of West Delta with special reference to its integrated management. Ph. D. Thesis, Fac. Agric., Al Azhar Univ., Egypt.

Godan, D.(1983). Pest slug and snails, biology and control. Springer verlag Berlin, Heidlberg $445 \mathrm{pp}$.

Hashem, A.G., Nakhla, J.M. and Tadros, A.W. (1992): Seasonal fluctuation in population of the land snails on citrus trees in the Northern reclaimed lands. Al.Azhar J. Agric. Res. 16:325 - 340

Hashem, A.G. Nakhla, J.M., Tadros; A.W and Korashy, M.A. (1993) Monitoring land snail on sweet orange trees in Beheira Governorate (Egypt). Zagazig J. Agri. Res., 20: $691-698$.

Hassanein, F.A. and Hamed, A.R. (1989): New recorded parasites of land snails infesting pear trees in Northen Coast of Egypt. Proc. $1^{\text {st }}$.Confi.Econ. Entom. 11:39 - 45

Hassan, N.A. (1999): Susceptibility of three sweet basil species (Oocmum spp.) to infestation of land snails and some insect pests. Adv. Agric. Res. Vol.4, No.1., $597-$ 609.

Iglesias, J., Castillejo J. and Castro R. (2003). The effects of repeated application of molluscicdes metaldehede and the biocontrol nematode phasmarhabditis hermaphrodita on mollusks earth worms, nematodes, acarids and collembolans: a two year study in north-west spain. Pest manag. Sci., 59: (12) 17-24.

Kassab, A. and Daoud, H. (1964): Notes on the biology and control of land snails of economic importance in U.A.R. Agric. Res. Rev. 42:77 - 98.

Nakhla, J.M; Tadros, A.W; Abd El Hafez, A.A and Hashem A.G. (1993): Survey and monitoring land snails in pear orchards at the Northern reclaimed lands. Alex. Scio., Exch. 14: $357-371$

Speiser, B. and Kistler C. (2002). Field tests with a molluscicide containing iron phosphate. J. Crop Protec., 21: 389-394.

Staikou, A.; Dimitriadou; M.L. and Pana, E. (1990); The life cycle, population dynamics, growth and secondary production of the snail Bradybaena fruticum (Muller) (Gastropoda: Pulmonata) in Northern Greece. J. Moll. Stud. 56: $137-146$. 


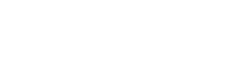

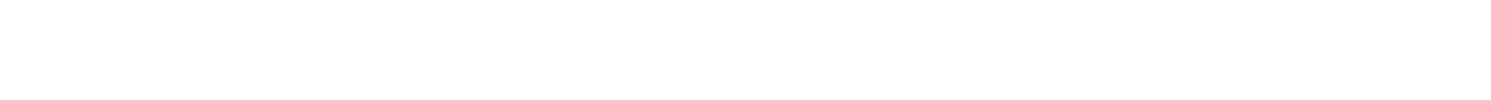 وابحة مهر \\ الميد هن عثره}

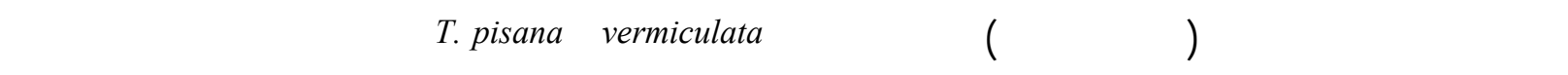

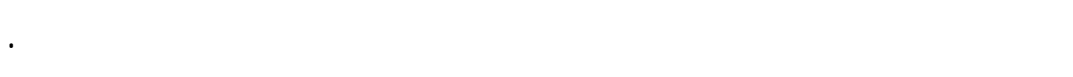
أوضهت الدرلة القتلية لن مظلم انواع القوفع الارضية

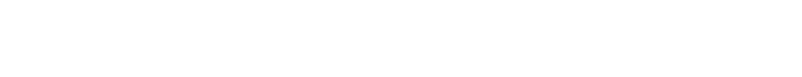

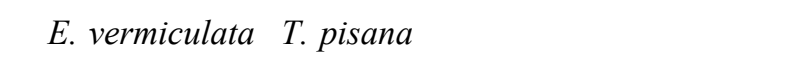

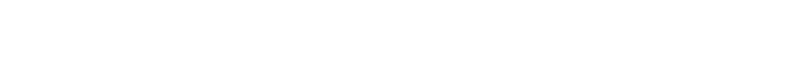

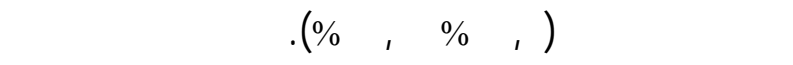
T. pisana ،E. vermiculat والثتملت على كلى من

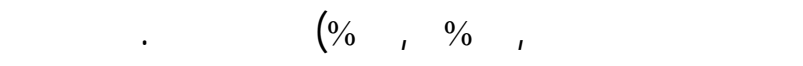

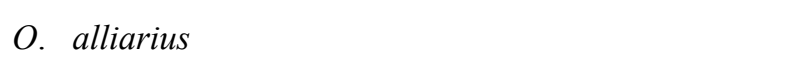
O M. obstructa , H. vestalis ,

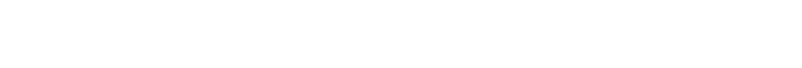

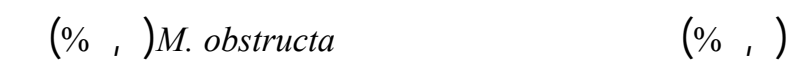

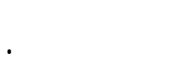

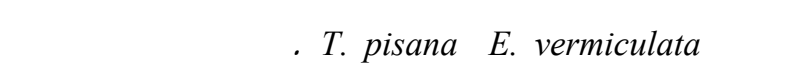

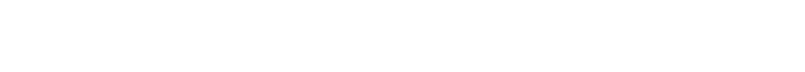
M. H. vestalis، T. pisana

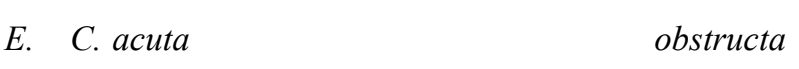

